\title{
A VIVENTE QUE GERA VIDA: ANALOGIA ENTRE O CORPO FEMININO E OS MISTÉRIOS DA CRIAÇÃO
}

\author{
The Living Being who Generates Life: Analogy Between the Female Body and \\ the Mysteries of Creation
}

Maria Clara Lucchetti Bingemer *

RESUMO: No presente artigo, se levanta a hipótese de que é possível pensar teologicamente a corporeidade da terra em analogia com a corporeidade da mulher. Em um primeiro momento, se critica alguns elementos dualistas que marcaram a linguagem teológica. Em seguida, se apresenta a teologia cristã da criação como processo que inclui a perspectiva de gênero; depois, se reflete sobre a terra como corpo da criação. Passa-se, em seguida, a examinar a corporeidade da mulher em dois sentidos: sua abertura e receptividade e sua capacidade de repartir-se e distribuir-se para alimentar a outros. $\mathrm{O}$ texto evolui na direção de afirmar que essa analogia pode gerar uma mística e uma ética: permite contemplar o mistério da terra e do feminino ao mesmo tempo em que reverencia e protege sua vulnerabilidade; privilegia o cuidado da vida e a volta à casa materna e comum que é a terra. Nessa última parte do texto, se trabalha com alguns extratos de textos da filósofa e mística francesa Simone Weil. A conclusão levanta algumas pistas teológicas para a superação do antropocentrismo que tem agredido a terra e a mulher neste momento histórico.

PALAVRAS-CHAVE: Terra. Mulher. Gênero. Criação. Ecofeminismo. Simone Weil.

ABSTRACT: This article rises the hypothesis that it is possible to think theologically about the corporeality of the Earth in an analogy with the corporeality of women. First, we criticize some dualistic elements that have shaped theological language. Next, we present the Christian theology of the Creation as a process which includes a gender perspective; then we reflect on the Earth as the body of

* Pontifícia Universidade Católica do Rio de Janeiro, Rio de Janeiro, Rio de Janeiro, Brasil. 
creation. We subsequently move on to examining women's corporeality in two senses: its openness and receptivity, and its capacity to share and distribute itself in order to feed others. The text evolves towards affirming that this analogy can generate a mystic and an ethic; it allows contemplation of the mystery of both the earth and the feminine, simultaneously revering and protecting their vulnerability. It privileges the care for life and the return to the maternal and common home; i.e., the Earth. In the last part of the text, we present some extracts from texts by the French philosopher and mystic Simone Weil. The conclusion raises some theological challenges to overcome the anthropocentrism which has been harming the Earth and women in this historical moment.

KEYWORDS: Earth. Woman. Gender. Creation. Ecofeminism. Simone Weil.

\section{Introdução}

$\mathrm{N}$

o texto que aqui apresentamos, propomos pensar teologicamente a corporeidade da terra em analogia com a corporeidade da mulher. Em um primeiro momento, levantaremos alguns elementos dualistas que marcaram a linguagem teológica ao longo da história. Em seguida, refletiremos sobre a teologia da criação como processo que inclui a perspectiva de gênero; depois, refletiremos sobre a terra como corpo da criação. Passaremos então a examinar a corporeidade da mulher em dois sentidos: sua abertura e receptividade e sua capacidade de repartir-se e distribuir-se para alimentar a outros. Aqui seguiremos o pensamento de Julia Kristeva. Procuraremos refletir em consequência que essa analogia pode gerar uma mística que contempla o mistério da terra e do feminino ao mesmo tempo em que reverencia e protege sua vulnerabilidade. E também uma ética que privilegia o cuidado da vida e a volta à casa materna e comum que é a terra. Ilustraremos essa parte de nossa reflexão com alguns extratos de textos da filósofa e mística francesa Simone Weil.

Esperamos em nossas conclusões apresentar algumas pistas teológicas para a antropologia e o cuidado da criação, bem como para a superação do antropocentrismo patriarcal e predatório que permearam o discurso cristão por muito tempo, levando a vida planetária ao ponto em que hoje se encontra, pondo sob ameaça a mãe terra e todas as suas criaturas.

\section{Dualismos que marcaram a teologia}

Existem diversos ângulos pelos quais se pode analisar e tipificar as diferentes religiões do mundo: o contexto em que surgiram, os grupos humanos que as praticam, seus sistemas rituais, seus corpus doutrinários, etc. A Teologia cristã, em seu esforço para falar a partir da Revelação e da fé, 
é chamada hoje mais que nunca a dialogar com as outras ciências a fim de autocompreender-se e compreender as questões que lhe são colocadas constantemente pelo tempo e pelo espaço onde está situada. Uma delas diz respeito às questões de gênero, cada vez mais candentes e desafiantes nos dias de hoje. Outra é a questão ambiental, que vai ocupando cada vez mais espaço na reflexão teológica e se anuncia como tema de ponta pelas próximas décadas.

Em uma primeira análise, buscando uma tipologia das religiões percebemos um modo de conceber a divindade ligado tanto a concepções de mundo como a concepções de gênero. Existem religiões ctônicas, telúricas, ligadas à natureza, à terra e seus ciclos. Assim são as religiões de matriz africana, as ameríndias e até algumas orientais (MORAES, 2017, p. 128-142; AUR, 2021). Outras são urânicas, mais verticais, enfatizando sobretudo a transcendência de Deus, e afirmando a supremacia do céu sobre a terra. $\mathrm{O}$ judeu-cristianismo se enquadra nessa segunda categoria. Introduz na história das religiões uma ideia e uma experiência totalmente transcendentes de Deus, que não faz número com nada do que existe, não tem sexo nem engendra filhos como os deuses gregos (ARMSTRONG, 1994, p 51-53). Apesar de estar constantemente em diálogo com a humanidade, esse Deus não pode ser por esta alcançado ou compreendido. Seu nome é santo - separado, outro - e não pode sequer estar em lábios humanos. A construção dessa religião é patriarcal, pois patriarcal era a cultura e o contexto onde nasceu e foi criada. Patriarcais são seus códigos, suas concepções, suas cosmovisões. E tal supremacia divina engendra por sua vez outras supremacias. À supremacia de Deus sobre o mundo e a humanidade corresponde à analogia da supremacia do macho sobre a fêmea, do homem sobre a mulher, do espírito sobre o corpo, do céu sobre a terra, etc. (BOFF, 1987, p. 47-58; BINGEMER, 1986, p. 73-99).

A primeira categoria que mencionamos - a das religiões telúricas - valoriza e torna o feminino mais visível, bem como faz forte e explícita conexão do mesmo com a terra, que tem ciclos como a mulher, as fêmeas e tudo que é feminino na natureza (BOFF, 1987, p. 47-58). Tal como a corporeidade feminina, toda a criação em seus reinos vegetal, animal e - dentro do animal - humano recebem sementes que crescem, dão flores e frutos. A terra é aberta e receptiva, como o corpo de uma mulher. Deve ser cultivada e tocada para receber as sementes que nela são depositadas. Tem ciclos e há que esperá-los a fim de que a fecundação aconteça. Ou será a mulher que é aberta e receptiva como a terra, não em vão chamada de "mãe" por tantas culturas originais e ainda mais recentemente pelo Papa Francisco: a nossa mãe terra? (LS, n. 1). No número 92 da mesma encíclica, o Papa se refere a todas as outras criaturas e, no final do parágrafo, chama o sol de irmão e a lua de irmã. Mas apenas ao mencionar a terra diz novamente: mãe terra (LS, n. 92). 
As Escrituras judaico-cristãs, no livro do Genesis, descrevem a criação situando a terra anteriormente ao ser humano e a todos os outros viventes. $\mathrm{O}$ Criador separa as águas da terra e enche a ambas de vida em multiplicidade de seres e espécies (Gn 1,7). O ser humano, o Adam macho e fêmea, homem e mulher, é, portanto, um ser posterior à mesma terra que pisa e da qual recebe seu sustento. O corpo imenso e maternal da terra o recebe ao nascer e o alimenta ao longo de sua vida. Este corpo fecundo e maternal da terra encontrará sua analogia no corpo da fêmea humana que - em semelhança com as fêmeas do reino animal - leva em seu ventre o novo ser e o traz à luz e à vida sobre a terra. E é igualmente a mesma terra que sobre seu corpo se fechará quando, sepultado, terminar seus dias. A terra, portanto, já na revelação bíblica, permite vislumbrar essa sintonia com o feminino.

Ao longo da história, no entanto, predominou na tradição judaico-cristã uma visão marcada pelo dualismo entre o céu e a terra, que gerou por sua vez uma visão de mundo e também uma visão de Deus. Baseia-se na separação estanque entre o que está acima - invisível, transcendente, sobrenatural - e o que está abaixo - palpável, imanente, natural. Da história das religiões e da psicologia religiosa aprendemos que a divindade - o ser ou seres divinos que a humanidade adora em todos os tempos e em todas as culturas - é sempre mediada pelo simbolismo arquetípico, respectivamente paterno e materno. A partir desse duplo simbolismo arquetípico, somos atraídos para dois tipos religiosos fundamentais (BOFF, 1987; BINGEMER, 1986, p. 73-99): um mais telúrico, orientado para a terra, a vida, a geração, os mistérios da morte, da natureza e dos seres vivos no cosmos: este está mais próximo da analogia materna. As religiões orientais e também as religiões afro-ameríndias, mais próximas de nós, sintonizam com esta tipologia (MORAES, 2017, p. 128-142; AUR, 2021).

O segundo é mais urânico, celeste, orientado para o céu, o infinito. Reivindica um Deus absolutamente transcendente, de quem o ser humano não pode se aproximar e continuar vivendo; que não se identifica com nada do que é criado, nem com as estrelas e os astros do céu (como na religião egípcia) (WIKIPEDIA, 2021b), nem com os ciclos da terra (como em tantas outras religiões) (WIKIPEDIA, 2021a; BEZERRA, 2021). Tampouco apresenta um panteão cheio de divindades especializadas e semidivindades como na Grécia (o deus do vinho, da música, da dança) (WIKIPEDIA, 2021c; BRANDÃO, 2015) Trata-se de uma divindade que não vem à terra nem mantém relações sexuais com mortais, como Zeus, que no ventre da humana Alcmena gerou Hércules (WIKIPEDIA, 2021d). Trata-se de uma religião mais paternal, voltada para o futuro, o fim da história, em busca de um projeto redentor e salvador, que surgirá no final de todas as coisas por mercê dos deuses e ação dos seres humanos. É uma religião diferente da primeira tipologia, mais voltada para os mistérios das origens: paraíso, criação, reconciliação primordial. Esse primeiro tipo é mais protológico, enquanto o segundo é mais escatológico. 
O modelo escatológico está mais em sintonia com o arquétipo e o conceito do masculino e a configuração que lhe foi atribuída em muitas civilizações antigas, inclusive a judaico-cristã: a marcha para a frente, a luta, a utopia, o combate. O ser humano é guerreiro e conquistador e Deus é sua matriz para a realização dessa finalidade. O protológico tem uma analogia mais sintonizada com o feminino e tudo o que implica a geração da vida: gravidez, parto, amamentação, cuidado. Obviamente, não se pode absolutizar nem um nem o outro isoladamente considerado e menos ainda identificado totalmente com um dos sexos (TORRÃO FILHO, 2021; OKA, 20211) ${ }^{1}$. Essa distinção aponta a um efeito didático, supondo, porém, que machos e fêmeas, homens e mulheres, sejam diferentes em seu bios, em sua corporeidade. O que questiona, no entanto, a teologia, é que o domínio de uns sobre os outros na construção de uma cultura, de uma civilização ou de uma religião, teve e segue tendo consequências importantes que não podem ser ignoradas. Acentua-se a seriedade da questão quando esta hierarquização dominante tem origem na fé e invoca Deus como seu fundamento e sua explicação.

Tanto o Judaísmo quanto o Cristianismo foram, desde sua origem até nossos tempos, religiões patriarcais, masculinas e eminentemente urânicas. O judaísmo introduz o monoteísmo - o culto a um só Deus - na história das religiões da humanidade, e isso representa um salto em relação ao politeísmo de outras religiões, tendo como consequência uma importante ruptura. Sendo inicialmente uma monolatria, estabelece-se como monoteísmo a partir da volta do exílio da Babilônia, com o consequente rompimento com as religiões de outros povos. Muitas dessas religiões identificavam suas divindades femininas com a natureza e seus ciclos: a terra, a fertilidade, a lua, etc. Seus deuses foram considerados como ídolos pela religião de Israel, e com tais ídolos o Deus verdadeiro não se mede nem faz número. Este não pode nem mesmo ser nomeado, já que isso limitaria sua infinitude e transcendência. No entanto, o mesmo Deus se aproxima do povo em amorosa identificação (Ex 3,6; At 7,32) 2 . Propõe um pacto, faz aliança e acompanha o povo em seu projeto, não se inserindo, porém, nos ritmos da terra e da natureza ou nos acontecimentos da história para modificá-los magicamente, limitando-se a acompanhar o universo e o ser humano em seus processos. ${ }^{3}$

\footnotetext{
${ }^{1}$ Os conceitos mesmos de masculino e feminino, com o avanço dos estudos de gênero, têm conhecido uma certa fluidez em suas definições. A teologia hoje, com o avanço dos estudos sobre o gênero em sua área, procura ser mais cuidadosa em separar radicalmente os dois gêneros e suas concepções.

${ }^{2} \mathrm{Cf}$. as passagens em que Deus se identifica como Deus dos seres humanos: Deus de Abraão, Isaac e Jacó, Deus de seus pais, Deus de meus pais, Deus de nossos pais: Ex 3,6; At 7,32 entre muitas outras.

${ }^{3}$ Pode-se discordar observando que a Bíblia hebraica apresenta Deus enviando catástrofes naturais agressivas sobre a terra, como o dilúvio por exemplo. O que queremos dizer aqui é que o Deus judaico-cristão não se imiscui nos processos do universo por ele criado, mas respeita sua autonomia, assim como a da humanidade.
} 
No cristianismo, com a Encarnação de Deus em Jesus de Nazaré e a expectativa do Reino, o sentido urânico permanece e se firma. O Cristianismo valoriza o corpo humano, uma vez que confessa que Deus se encarnou, foi concebido e nasceu de mulher (Gal 4,4). No entanto, embora esse seja o artigo central da confissão de fé cristã, nem sempre a comunidade eclesial incluiu em seu pensar e em seu discurso todas as consequências desse mistério. A visão dualista que hierarquiza o espírito sobre o corpo predominou no cristianismo histórico (BROWN, 1990; COSTA, 2018, p. 185-204). Esse fato marcou sobremaneira o judeu-cristianismo em sua nomeação e em sua concepção de Deus. As coisas do espírito receberam nomes masculinos e as femininas foram identificadas com a matéria e o pecado. $\mathrm{O}$ masculino passou a ser a linguagem predominante para dizer o mistério maior que se chama Deus (BORRESEN, 1983, p. 17-32; 1976, p.18-29).

O judeu-cristianismo passou então a ser uma expressão religiosa de predomínio vertical - diferente da expressão telúrica centrada nos mistérios da vida e da morte - com uma visão antropológica na qual o masculino é a imagem por excelência do divino. A cosmovisão daí derivada privilegia o céu sobre a terra, o vertical sobre o horizontal, o futuro sobre a origem, fundamentando esses privilégios no próprio ser e na própria essência de Deus. Os nomes pelos quais Deus é chamado serão predominantemente masculinos, refletindo a configuração acima mencionada (BINGEMER, 2008, p. 45-56).

O advento da teologia feminista, no século XX, trouxe uma visão bastante crítica sobre este problema. Mesmo teólogos homens, entre eles o protestante Jürgen Moltmann afirma no livro que escreveu com sua esposa Elizabeth Moltmann Wendel (MOLTMANN, 1984), que há pouca relação entre este Deus e o Abba de Jesus. «Pelo contrário, este Deus patriarcal nasceu desta divisão inicial do mundo entre o céu e a terra...» (MOLTMANN, 1984, p. 132). A nomeação de Deus no Cristianismo permanece até hoje, consequentemente, marcada pela linguagem patriarcal e dualista que configurou suas primeiras expressões. Essa concepção teve ramificações igualmente graves que questionam a teologia. Entre essas, se encontra principalmente o machismo, aqui entendido como vulgarização do patriarcalismo. O varão é o protótipo do humano em sua plenitude, afetando assim a concepção de humanidade. No momento em que o Cristianismo transpôs a fronteira do Oriente Médio onde nascera e se espalhou por todo o Ocidente, esse homem varão adicionou a sua auto concepção o elemento racial e étnico: branco e europeu. Tudo o que não se enquadrasse nesta matriz passou a ser considerado "outro", "diferente" e - velada ou explicitamente -"inferior". E isso foi visto como "natural", já que obedecia a uma lei incontestável (MIGNOLO, 2017; SANTOS; MENEZES, 2010).

Pertence, portanto, à ordem natural - e, logo, religiosa e divina - que a mulher se submeta ao homem, que o negro seja escravo do branco, que os indígenas sejam considerados selvagens e primitivos, e assim por diante. 
Deste modo, mulheres, indígenas, negros, asiáticos, homossexuais e toda a imensa riqueza da diversidade que conforma a humanidade são obrigados a entrar no molde da concepção ocidental predominante durante muitos séculos nesta parte do mundo. ${ }^{4} \mathrm{O}$ masculino é identificado com tudo o que está acima, no alto, pertencente ao nível "celeste": o espírito, o conhecimento, a ciência, a organização do sagrado e do religioso. $\mathrm{O}$ feminino, ao invés, é matéria, é corpo, é terrestre, pois vem de baixo, devendo ser subjugado e dominado, já que é inferior.

A outra consequência deste dualismo que nos interessa de perto é o antropocentrismo. O mandato de "dominar a terra", que o livro do Gênesis $(1,28)$ põe na boca do Deus Criador dirigido à criatura recentemente moldada em barro e animada com o sopro da vida divina, sofreu muitas interpretações em toda a tradição cristã. Mas uma delas prevaleceu, tendendo a interpretar a orientação divina no sentido de um mandato ao qual se deve obedecer literalmente, já que é vindo de Deus. Isso gerou uma atitude de domínio arrogante do ser humano sobre a natureza, em nome do Criador. Essa interpretação, no entanto, pertence a uma tendência entre tantas outras, apresentando uma visão antropocêntrica com conotações predatórias em relação à natureza. Ultimamente, outras tendências contestaram o antropocentrismo de conquista, sobretudo com o crescimento da consciência ecológica. Introduziu-se uma perspectiva contemplativa na identidade do mundo criado, considerando-o como casa a ser cuidada, amada e respeitada, além de sacramento de Deus e espaço de salvação (BINGEMER, 1992, p. 77-87). A Encíclica Laudato si', do Papa Francisco, de 2015, é como um marco nesse processo.

A interpretação do mandato genesíaco na direção de uma primazia absoluta e ilimitada do homem sobre a natureza teve, porém, outras consequências, como a suspeita de uma concepção erroneamente individualista do ser humano, aliada a um determinismo econômico e tecnológico onipotente e prepotente. E, acima de tudo, conduziu a uma visão da natureza, da terra, do cosmos separados do ser humano, cindindo assim a Criação de Deus. O humano passou a ver a natureza como um inimigo a ser conquistado e destruído impunemente em nome de um progresso e enriquecimento errôneos e ilícitos. A luta do ser humano pela vida foi então transformada em ameaçador e agressivo instinto de morte que pesa sobre todas as outras formas de vida $(\mathrm{BOFF})^{5}$. Escolher tal interpretação, originada do

\footnotetext{
${ }^{4}$ É digno de nota todo o esforço que já se fez por parte da teologia para superar este estado de coisas. Veja-se por exemplo a teologia feminista e de gênero, afro, indígena e, mais recentemente, tentando um esforço mais amplo de reflexão, a teologia decolonial, que conecta as diferentes discriminações, além de integrar cosmovisões ancestrais, e a crítica ao projeto colonizador que vem junto à religião, em geral cristã, católica ou protestante. A teologia decolonial é um esforço epistemológico relevante sobre todas essas interpelações.

${ }^{5}$ Cf. sobre isso toda a obra de Leonardo Boff, que denuncia sistematicamente esse estado de coisas. Na Encíclica Laudato si' do Papa Francisco, igualmente se encontra essa visão crítica sobre uma certa visão antropocêntrica, embora se use o termo antropocêntrico incorporando uma visão crítica.
} 
dualismo que expusemos anteriormente, é introduzir uma cisão irreparável na própria ideia de criação, separando o humano do resto do criado e fazendo uma ruptura e cisão mortais na vida entendida como um dom do Deus Criador, o qual é vida em si mesmo.

\section{Criação: um processo que não nega o Criador}

O livro do Gênesis diz que "No princípio criou Deus os céus e a terra." Ou, "no princípio de tudo, Deus criou o céu e a terra" $(1,1)$. Na fundação do mundo, portanto no início de tudo, Deus criou os céus, a terra, o universo, enfim. Essas palavras, com as quais a Bíblia inicia, apresentam duas verdades de fé importantes. Primeiro, "os céus e a terra", ou o universo físico, tiveram um começo. E em segundo lugar, foram ambos criados por Deus. São originados do poder criador do mistério maior da vida que é - esse sim - eterno e sem origem (STEINER, 2006, p. 232-248; ROCHA, 2010, p. 10-39).

Ousaríamos acrescentar uma terceira verdade: o céu E a terra foram criados no princípio. Não nos diz o texto bíblico que o Criador inicie sua ação criativa primeiro pelos céus e depois pela terra. Tampouco insinua qualquer impressão, em todo o relato da criação, de que os céus e aquilo que é "de cima" sejam mais importantes do que a terra. Os céus e a terra foram criados no início de tudo. As estrelas e luzes do céu são criadas e postas no firmamento por Deus para iluminar a terra. Estão, portanto, a serviço da terra. Em outras palavras, não existe primazia do céu sobre a terra. Tal hipótese hierarquizante não aparece no relato sacerdotal (Gn 1, 14) e nem no relato Javista ( $\mathrm{Gn}, 2,4-6)$.

Por outro lado, aparece, sim, um carinho e um cuidado desvelado do Criador para com a terra. Além de iluminá-la com os luzeiros do firmamento, Ele a povoa de vida, em imensa diversidade de formas e espécies. E do lodo da terra fez - segundo o Javista - o homem (ish), e como não era bom para este ficar sozinho, de sua costela tirou uma ajuda, uma companheira, a mulher (isha) (Gn 2, 7-8. 18. 21-23). A criação, no relato genesíaco, acontece no plural, e não é de um indivíduo e muito menos concede a algum indivíduo mais importância em relação a outros. $\mathrm{O}$ verbo se encontra no plural: "Façamos o homem ('ādām= ser humano) à nossa imagem, como nossa semelhança e que eles dominem..." (Gn 1,26). No entanto, esse plural é comunitário. $\mathrm{O}$ "adam" criado não é somente um nem vários dispersos e separados, mas sim um coletivo singular, que significa o "ser humano", a "humanidade" (DELLAZARI, 2006, p. 731-746). Igualmente é clara a configuração desse coletivo, quando o texto diz que ele (o Criador) "homem [zākār] e mulher [neqēbāh] os criou" (Gn 1,27) (DELLAZARI, 2006, p. 731-746). Já no relato javista, no mesmo livro do Gênesis, a palavra para designar a mulher que foi tirada da costela do homem (isch) será 
isha: "ela será chamada 'mulher' (ischa), porque foi tirada do homem (isch)" (Gn 2,23) (ADINOLFI, 1981, p. 36).

A imagem de Deus está selada na carne humana, tanto masculina (zakar -isch) quanto feminina (neqēbāh - ischá). E o capítulo 2 dirá no v. 7: “E formou o Senhor Deus o homem do pó da terra, e soprou em suas narinas o fôlego da vida; e o homem foi feito alma vivente". O adam (homem e mulher, macho e fêmea) é feito da terra, do barro, do elemento árido que foi criado "no princípio". Pertence à terra, é terra. E o espírito (nefesh) soprado em suas narinas não está acima dele, mas em seu interior. O ser humano não é uma divisão entre um corpo de matéria mortal e inferior e uma alma superior e imortal. É um corpo animado pelo espírito divino. É “alma vivente" segundo Gn 2,7 (ALLMEN, 2001, p. 131). ${ }^{6}$

A imagem que sobressai da terra na história do Gênesis é a de sede e mãe da vida. Seu grande corpo é hospedeiro e gerador da vida. De seu útero brotam todos os seres vivos, incluindo os humanos, sendo todos feitos de sua substância. Feitos da terra, animados pelo espírito de Deus, isso somos. Somos terra. Leonardo Boff fala sobre essa nossa dimensão terrestre constitutiva: "O que significa nossa dimensão terrestre? Significa, em primeiro lugar, que somos parte integrante da Terra. Nós viemos dela. Somos o produto de sua atividade evolutiva. Temos elementos da Terra no corpo, sangue, coração, mente e espírito. Essa compreensão resulta em uma consciência de profunda unidade e identificação com a Terra e sua imensa diversidade. Não podemos cair na ilusão racionalista e objetivista de que estamos encarando a Terra como se estivéssemos diante de um objeto estranho. No início, existe uma relação sem distância, sem vis-à-vis, sem separação. Somos um com ela" (BOFF, 2021; BOFF, 1999).

E é o mesmo Boff quem destaca que essa sintonia do humano com a terra reflete a dimensão materna. É a nossa Mãe Terra. Porque nos sentimos filhos e filhas da Terra, porque somos a Terra pulsante e amada, nós a vivemos como Mãe. Ela é um princípio gerador. Representa o Feminino que concebe e dá à luz. Assim surge o arquétipo da Terra como a Grande Mãe, Pacha Mama, Nana e tantos outros nomes. Da mesma forma que tudo gera e dá vida, a Terra também tudo acolhe em seu seio. Quando morremos, voltamos para a Mãe Terra. Voltamos ao seu útero generoso e fértil (BOFF, 2021).

Essa experiência de que somos Terra constituiu a matriz do processo de autoconsciência da humanidade. A terra é nossa mãe e todos temos em nós seu código genético, fornecido por sua identidade materna e direta. De seu seio saímos e de sua substância somos feitos. Ela é nossa matriz arquetípica e não estamos dela separados, mas sim em seu corpo, com sua

\footnotetext{
${ }^{6}$ Sobre o significado de "nefesh": Jean-Jacques Allmen afirma que o nefesh é o sopro da vida que somente Deus pode dar a sua criatura. O ser humano só existe na medida em que recebe o sopro da vida, que Deus lhe dá em ato soberano.
} 
identidade. Dessa experiência matricial surgem então uma mística e uma ética configuradas pela corporeidade feminina e as instituições matriarcais. Da terra aprendemos que a mulher é o primeiro eixo organizacional da sociedade e da cultura. A corrente de pensamento denominada ecofeminis$\mathrm{mo}^{7}$, da qual a teologia participa com o que lhe é próprio, tem se debruçado sobre essa questão e lançado reflexões e desafios que enriquecem o atual momento em que vivemos: uma imensa crise ecológico/humanitária.

\section{Mulher e Terra: corporeidades abertas e vulneráveis}

Entre as múltiplas riquezas que o pensamento ecofeminista tem trazido para a teologia, uma das mais importantes é haver levantado a hipótese de que a associação entre a dominação das mulheres e a dominação da natureza é própria das culturas patriarcais e particularmente da nossa, a cultura ocidental. Essa hipótese diz ainda que, na medida em que sejam construídas e reforçadas relações mais equilibradas entre humanidade e natureza, como pretende o pensamento ecológico hoje, isso, por si só, resultaria na superação da dominação das mulheres pelos homens (CANDIOTTO, 2012, p. 1395-1413).

No entanto, a história demonstra que ambas as dominações surgiram em momentos históricos diferentes, separadas por muitos séculos de distância. A dominação das mulheres é muito mais antiga do que a exploração irresponsável da natureza. O patriarcalismo existe há vários milênios, com a consequente opressão das mulheres, enquanto a exploração da natureza coincide com o início da modernidade, a autonomia da ciência e o processo de secularização (GEBARA, 1997, p.11). Porém, embora se relativize a conexão linear entre mulher e terra, encontrando a solução para ambas as dominações no processo de libertação de uma delas, não se pode negar a estreita relação analógica entre ambas.

A chave para o problema estaria, teologicamente, na concepção bíblica e revelada de criação, a qual deixa evidente que a natureza precede a humanidade e, portanto, a cultura. Se a natureza é posterior porque criada, a humanidade com mais razão o seria, já que é constitutiva da mesma natureza em comunhão com os outros seres vivos. Apenas em um momento segundo começa a produzir o que se entende por cultura. Sendo o patriarcalismo uma concepção cultural que invoca sobre si mesmo a bênção da lei natural, o processo de reinserção da comunidade humana dentro do conjunto do meio ambiente e do ecossistema pode, sem dúvida,

\footnotetext{
${ }^{7}$ Ecofeminismo é o movimento e escola de pensamento que liga o feminismo com a ecologia. $\mathrm{O}$ termo é creditado à escritora francesa Françoise d'Eaubonne, em seu livro Le feminisme ou la Mort (1974). Outras pensadoras aderiram a este movimento que preconiza a morte da natureza e da vida se não se passar pelo feminismo, ou seja, pela libertação da mulher.
} 
ajudar a restaurar uma relação mais correta e reconciliada não somente dos seres humanos com a natureza, mas do macho com a fêmea, do homem com a mulher (CANDIOTTO, 2012, p. 1395-1413). Entretanto, há correntes teológicas ecofeministas que não cessam de alertar contra o perigo de se acreditar que lutando pela superação da crise ecológica, automaticamente se terá resolvido a questão da opressão da mulher. Apesar da estreita conexão entre a mulher e a terra, a luta específica da primeira sem dúvida merece um investimento à parte sob pena de ser despotencializada se for inteiramente identificada à luta ecológica (SOUZA, 2000, p. 61) . $^{8}$

Na verdade, o feminino configura os arquétipos das origens das agremiações humanas. As mulheres constituem os eixos organizacionais da sociedade e da cultura (BOFF, 2000, p. 30-32). Sua identificação com a terra fez surgir sociedades sagradas que reverenciaram a vida em diversas expressões religiosas. Como aponta Boff, todos levamos em nós a nostalgia da Mãe Terra em nossos desejos de integração e reconciliação universal. O arquétipo materno da terra, que encontra analogia no corpo das fêmeas, inclusive aquelas da espécie humana, remete-nos a uma origem fecunda do mistério da vida, que necessita ser resgatada e ganhar pleno destaque nas diversas áreas do saber e especialmente na teologia. Em um mundo configurado pelo patriarcado, o feminino se apresenta no horizonte com cada vez mais força, atraindo e fazendo surgir novas formas de viver e de pensar (BOFF; MURARO, 2002). A crise ecológica e, na teologia, o crescimento do pensamento ecofeminista e a força do apelo à conversão ecológica são momentos propícios para uma mística de "volta à casa da mãe" que hoje acontece e atrai a tantos. ${ }^{9}$

A terra é o corpo da criação. E esse corpo funciona de forma análoga ao que observamos no corpo feminino. Tem ciclos, é receptivo e permeável à penetração do outro. Fecundado, dá frutos. Maltratado, sugado e explorado sem limites, seca e se torna estéril. Trata-se de um corpo vivo que encontra sintonia com a abertura, receptividade e fecundidade que acontecem no corpo da mulher, a qual por sua vez evoca a terra semeada e fecundada. Assim o dizem os compositores Milton Nascimento e Chico Buarque em sua canção Cio da Terra: "Afagar a terra/Conhecer os desejos da terra/ Cio da terra, a propícia estação/E fecundar o chão" (YOUTUBE, 2021h).

Por isso, afirmamos que o corpo da terra encontra no corpo da mulher, filha de Eva, sua primordial analogia. Eva, mãe dos viventes, é aquela cujo nome não é substantivo, mas verbo: viver. Assim como a terra, a mulher é a analogia privilegiada para a compreensão e interpretação da Criação e nela de tudo o que vive. O próprio nome Eva significa "a que

\footnotetext{
${ }^{8}$ Segundo Sandra Duarte de Souza, no pensamento de ecofeministas como Rosemary R. Ruether e Anne Primavesi, "existe a predominância de uma abordagem ecológica, que insiste estar na redefinição da relação humana com a natureza, a redefinição das relações sociais, particularmente, das relações sociais de sexo".

${ }^{9}$ Essa expressão foi utilizada pela filósofa e teóloga Ivone Gebara por ocasião da recepção do Prêmio João Batista Libanio, a ela outorgado pela SOTER, em 15 de julho de 2021.
} 
vive", "a vivente", "a que tem vida" ou "cheia de vida". Tem origem no hebraico Hawwá, Havah, derivado da raiz hawá, que quer dizer "ela viveu" e, portanto, lhe é atribuído o significado de "a que vive", "a vivente" (EVA, 2021g). Essa "vivente" aparece nos primeiros capítulos do livro do Genesis saída das mãos do Criador.

Os dois primeiros capítulos do Gênesis usam dois termos diferentes para identificar o masculino e o feminino. Gn 1 fala de zākār varão e neqē $\bar{a} h$ varoa. Gn 2 usa os termos isch (homem) $\mathrm{e}_{\tau}$ ischa (mulher)-. Essa diferença entre os relatos sacerdotal (capítulo 1) e javista (capítulo 2) deve ser olhada com atenção.

O autor de Gênesis 1 diz apenas que o ādām foi criado varão e mulher. A diferenciação sexual não é enunciada apenas em termos sociopsicológicos de varão (isch) e varoa (ischa) (Gn 2), mas também na de macho (zakar) e fêmea (nekeva) (Gn 1). A palavra zakar significaria "o pontudo" e nekeva, "a perfurada" ou transpassada (ZOLLI, 1935, p. 146-148). O sentido de fundo de nekeva parece significar fazer um buraco, ser perfurado. Nesse sentido, se associa ao feminino com o sentido de deflorar, romper, abrir. Mas não apenas no sentido sexual de romper o hímen da virgindade, mas igualmente com o significado simbólico de abertura, de caminho por onde passa a vida e penetra a alteridade. Se o falo é fechado e externo, o corpo da nekeva é aberto, perfurado e sua interioridade misteriosa. E por meio dessa corporeidade, o feminino pode revelar mistérios e evocar e comunicar experiências de forma única. Essa potencialidade passa pelo que é constitutivo de sua corporeidade cíclica, aberta, fecunda, habitada, fonte e morada da vida.

A psicanalista Julia Kristeva escreve sobre esta questão. Kristeva dá enorme importância em sua reflexão ao corpo feminino, inclusive em sua relação com o sagrado. Em um de seus livros, dialoga com a filósofa e escritora Catherine Clément. Ambas, em sua correspondência, trocam afirmações importantes e originais sobre este tema. Afirmam, por exemplo, que com ou sem gravidez, "o corpo da mulher não cumpre integralmente as normas da sociedade. Seu ciclo natural não corresponde aos meses do ano nem está de acordo com os calendários da cidade moderna" (KRISTEVA, 2015, p. 87). Acrescentamos: nem da sociedade, nem da natureza, nem da cultura. $\mathrm{O}$ corpo da mulher obedece à vida e suas reivindicações e exigências, na alteridade do que lhe é dado em realidade ou em potencial.

Kristeva atribui enorme importância à redescoberta da corporeidade feminina, da porosidade e fertilidade que a caracteriza, algo que as feministas da primeira, segunda e até terceira onda - segundo ela - parecem não fazer. E valoriza muito este ponto não só em sua reflexão como psicanalista, nas análises sociológicas, mas também na reflexão estética e nas artes. Uma de suas artistas visuais favoritas é Georgia $\mathrm{O}^{\prime}$ Keefe, pintora estadunidense do século XX, identificada dentro da corrente chamada "modernismo", que se destacou especialmente pelas esplêndidas e exuberantes pinturas de flores. 
Kristeva vê na pintura de O'Keefe o belo e assustador impulso da sensualidade feminina (WIKIPEDIA, 2021f; KRISTEVA, 2007; 2005). A artista pinta a beleza renascida de tudo que está vivo tal como o vivem as mulheres, porque elas o carregam em seu útero fértil. Nesse sentido, a corporeidade feminina acompanha a configuração das flores em sua fertilidade, sua vitalidade, sua explosão de vida e alteridade" (MASDEARTE.COM, 2021k).

É por isso que a pintura de O'Keefe inspira e interroga Kristeva. A pintora trabalha com imagens que associa às mulheres. Assim, a flor que foi apropriada pelo machismo e por vezes é símbolo alienante, em sua pintura é apresentada no ápice do erotismo e da sensualidade, chegando aos limites da provocação. Kristeva não hesita em dizer que as flores de O'Keefe sugerem a aparência de genitais femininos (KRISTEVA, 2013, p. 496-498). Para ela, porém, a pintora com suas flores sensuais foge do clichê e do comum, guardando em suas criações estéticas um mistério que questiona. A sensualidade está presente, mas inextricavelmente ligada à fertilidade.

No entanto, não são apenas as flores de O'Keefe que impressionam e desafiam o pensamento de Kristeva. Também há imagens de ossos que mostram a pelve feminina como um buraco, um vazio, uma abertura para o infinito. E esse preciso sentido já está contemplado na palavra hebraica nekeva, como receptáculo, espaço aberto para a interioridade. A corporeidade feminina, aberta, receptiva, disponível para a fecundação e a entrada do outro posteriormente explodirá em fertilidade e beleza como a das flores. Mas também poderá ser ressecada e despojada de seu revestimento até ficar como os ossos da pelve secos e esterilizados pelas agressões sofridas (FLICKR, 2021i).

Kristeva é feminista sem dúvida alguma. Diz mesmo às mulheres que os únicos que têm a perder são suas cadeias (KRISTEVA, 2013, p. 17). Mas também critica o que a sociedade moderna e uma certa corrente feminista tem feito com as mesmas mulheres, ainda quando quer empoderá-las. Golpeia-as com a mentira de que poderiam protelar a maternidade indefinidamente. Isso leva muitas a se frustrarem, quando o relógio biológico dá sinais de esgotamento e elas desejam ser mães, mas já não podem sê-lo. Segundo a psicanalista, o sucesso profissional não atendeu a todos os anseios da mulher, e sua libertação passa por algo mais totalizante e holístico do que apenas o progresso profissional ou financeiro (KRISTEVA, 2013, p. 54-55).

Para Kristeva, à tríade francesa da qual se sente admiradora e devedora - liberdade, igualdade e fraternidade - deve-se acrescentar uma quarta dimensão: a vulnerabilidade. E, para ela, essa vulnerabilidade levará à maternidade, metáfora poderosa para as mulheres e toda a espécie humana. Do ponto de vista da teologia, esta metáfora é igualmente poderosa para a criação e dentro dela a terra. $\mathrm{O}$ feminismo da primeira onda suspeitou da maternidade como possível fonte de escravidão para as mulheres. $\mathrm{O}$ feminismo europeu de Kristeva denuncia esse feminismo inicial e resgata um feminismo onde as mulheres precisam redescobrir a vulnerabilidade, 
mas também a beleza de seus corpos vulneráveis e potencialmente férteis. Segundo ela, há que valorizar a maternidade como poder e não como fardo escravizador (KRISTEVA, 2013, p. 75).

No continente latino-americano durante os anos 60 e 70, a experiência libertadora e a prática profética de muitas mulheres giraram em torno da maternidade da qual se tornaram "órfãs" devido ao poder sinistro da opressão de diversas ditaduras. Muitos corpos femininos foram agredidos pela tortura esterilizante, assim como muitos corpos de mães tiveram seus úteros violados pela expropriação dos filhos, desaparecidos, torturados e mortos e pela subtração dos netos, entregues a famílias outras para serem criados. Hoje, outro tipo de violência continua a ocorrer. Muitas mulheres na AL têm sido atacadas e mortas pelo simples fato de serem mulheres. $\mathrm{O}$ feminicídio aumenta exponencialmente e os corpos femininos são destroçados e desaparecidos pelo ataque irresponsável e violento de um machismo destruidor (WIKIPEDIA, 2021e).

Tal como essas mulheres, a terra expropriada, espoliada e irresponsavelmente atacada teve seu corpo esterilizado e sua maternidade feita órfã. Porém, tal como as mulheres agredidas, a terra resistiu e busca reencontrar o caminho da vida desobedecendo ao poder opressor que lhe dita regras de comportamento e submissão. Assim, assistimos hoje às desconcertantes mudanças climáticas, que fazem o gelo ártico derreter sob um calor inusual e os trópicos tremerem de frio como nunca. Chuvas torrenciais caem fora de época e secas inusitadas têm como resultado um fogo implacável que destrói florestas, plantas e ameaça seres humanos. Um vírus de $5 \mathrm{~mm}$ põe a orgulhosa humanidade de joelhos, devendo a ciência redescobrir pacientemente o caminho para vacina e cura (BOFF, 2021).

Assim como a terra que se defende contra um antropocentrismo mal compreendido e irresponsável, as mulheres descobrem o caminho de insurreição contra a agressão a seus corpos e fazem ouvir seu lamento coletivo. Esse lamento ecoa e encontra respaldo nas mulheres da Bíblia que foram capazes de desobedecer a um poder opressor e patriarcal em função da defesa da vida. (CANDIOTTO, 2015, p. 200-215). E assim como essas ancestrais, as mulheres descobrem uma experiência mística que lhes mostra o cuidado da terra e da vida como caminho para a união com o Deus da vida.

\section{Por uma mística ecofeminista}

Para tomar consciência da revelação do mistério no feminino e de sua proximidade com a criação é preciso, no entanto, de um esforço epistemológico. Segundo Ivone Gebara, a tarefa epistemológica na perspectiva de gênero é mostrar que "o "conhecimento" no sentido religioso pode ser um caminho de Justiça e de Amor, ou de Submissão e Injustiça, se 
não estivermos atentas(os) para o fato de que contém uma força incrível." (GEBARA, 1997, p. 27).

Por isso é fundamental recuperar a experiência e, embora resgatando e incorporando o passado, não concebê-la e afirmá-la isoladamente, dissociada do imenso Corpo no qual estamos integrados todos e todas. Para viver e construir uma mística onde o feminino e o cósmico sejam valorizados, será preciso que nessa experiência cresça, constantemente, a consciência do que somos: somos corpo dentro de um Corpo (SHIVA, 2004).

Somos homens e mulheres, somos seres humanos, mas somos terra, e nesta terra vivemos e convivemos com milhares de outros seres vivos. Somos humanidade, mas somos também cosmos. Todas as portas de entrada de nossos sentidos estão, sejamos ou não disso conscientes, impregnados por todos os elementos desse cosmos, desse mundo criado por Deus. A partir do ato de respirar, percebemos o ar e sua importância e necessidade vital. Inspiramos, expiramos, e a vida segue acontecendo em nós graças ao ar que nos renova a partir de nossa interioridade. Com o tato percebemos a textura e a pele que reveste outros corpos e sentimos sua proximidade, seu carinho, ao mesmo tempo em que experimentamos atração por eles. Nossa exterioridade se redescobre em cada contato com outra exterioridade e nesse contato está presente a energia vital que circula em todo o planeta (GEBARA, 2008).

A experiência mística é sempre uma experiência de união e integração. E hoje, em tempos de crescimento da consciência ecológica, o elemento cósmico, o elemento terra, o elemento corpóreo, não podem estar ausentes dessa experiência. Deve ficar longe a concepção que nos diz que somos um corpo de pecado e morte, e uma alma, essa sim, imortal e eterna. Somos um corpo animado e habitado, e a revelação que nos diz isso que somos se dá na vida que é real e ao mesmo tempo efêmera; que é sentida e que fenece como tudo que é vivo.

Por isso, essa mística corpórea é chamada a valorizar o aqui e agora, "o efêmero, o momento que passa, o pôr de sol, a flor, a morte. Efêmera é a vida e o conhecimento,

efêmera e misteriosa é a sabedoria (GEBARA, 2008, p. 66). A corporeidade feminina e a corporeidade da terra com todas as formas de vida são, portanto, mediações para a compreensão e interpretação do mundo, do ser humano e para a experiência de Deus.

Toda mística é experiência do mistério, mas também experiência de conhecimento. Em uma mística que integra o feminino com a terra e o cosmos, acontece igualmente um progresso no conhecimento. E esse conhecimento é inseparável do amor. Conhecer o corpo próprio e alheio, conhecer a terra, o grande corpo onde todos os seres vivos estamos inseridos e integrados significará não a dominar, não a reduzir, não instrumentalizar, mas se 
colocar, modesta e "maravilhadamente", na escola do amor que olha, vê com respeito e busca integração (BINGEMER, 1992, p. 77-87).

Nesse ponto, o feminino, com sua corporeidade aberta, será a analogia paradigmática dessa experiência com sua vulnerabilidade perfurada e permeável, receptiva à revelação de toda forma de vida e à recepção de toda vitalidade que vem da alteridade, da terra e da diafanidade do Espírito que a habita e configura, soprado que foi desde o princípio nas narinas do adam, do humano. A mística que integra corporeidade e terra convida a cada um a redescobrir quem é como espécie humana. Convida a resituar-se dentro do tecido da comunidade da vida, buscando aí um caminho para deter a morte e a destruição da criação (RESS, 2010, p. 112).

Nesse processo analógico entre a mulher e a terra, impõe-se a metáfora do corpo. A mulher traz em seu corpo os processos que a terra vive em esfera maior e infinitamente multiplicados. A corporeidade feminina metaforiza o grande Corpo Sagrado da terra, sede da vida, onde habita o Espírito vivificador. A mística que aí acontece, portanto, só pode ser uma mística da experiência do divino como vida em plenitude mediada pela vulnerabilidade e a beleza dos processos vitais da terra, dos quais a corporeidade da mulher é analogia primordial.

Segundo Mary Judith Ress, a opressão da mulher e a destruição do planeta são duas formas da mesma violência, da mesma necessidade de controlar o mistério em sua diferença inefável. A corporeidade da mulher e a corporeidade da terra são misteriosas porque são fonte de vida. O sistema antropocêntrico predatório e patriarcal as vem tratando como meios, recursos (RESS, 2010, p. 113). E isso tem como consequência a ameaça mortal à vida e às diferentes espécies. Em meio ao reconhecimento da diversidade das formas de vida, a mulher e a terra se reconhecem como tendo uma fundamental afinidade e parentesco (RESS, 2010, p. 114).

A mística que emergirá deste reconhecimento recíproco vai trazer a consciência fundamental do corpo e da experiência corpórea como fonte de todo conhecimento. A vulnerabilidade do corpo, onde habitam e acontecem o gozo e a dor, o sofrimento e o júbilo são o terreno de experimentação que desvelam o conhecimento do bem e do mal, do Amor e da Vida (RESS, 2010, p. 114). E esse corpo é o corpo real, sexuado, genital, da nekeva, da fêmea, poroso, perfurado e aberto, por onde entra e sai a vida que habita toda a criação.

Nesse sentido, a experiência mística feita a partir da corporeidade aberta à fecundação e à fertilidade resgatará o Eros dominado que construiu um imaginário dualista e opressor. Resgatará igualmente a solidão da corporeidade, abrindo-a ilimitadamente à comunhão com tudo que vive e existe. A inocência e beleza vital do corpóreo é o selo característico dessa mística feita de argila e carne atravessadas pelo sopro vital do Espírito. 
As palavras da poeta brasileira Adélia Prado podem dizer melhor o que os conceitos se sentem impotentes para enunciar:

"É inútil o batismo para o corpo,/O esforço da doutrina para ungir-nos,/Não coma, não beba, mantenha os quadris imóveis./Porque estes não são pecados do corpo./À alma sim, a esta batizai, crismai,/Escrevei para ela a Imitação de Cristo./O corpo não tem desvãos,/Só inocência e beleza,/Tanta que Deus nos imita/E quer casar com sua Igreja/E declara que os peitos de sua amada/São como os filhotes gêmeos da gazela./É inútil o Batismo para o corpo./O que tem suas leis as cumprirá./Os olhos verão a Deus." (PRADO, 1999, p. 320).

A mística da corporeidade feminina e ecológica revela igualmente que, além de ser criado e animado por Deus, fecundo e frutífero, o corpo da mulher alimenta os filhos que lhe saem do ventre assim como a terra o faz. E como os alimenta? Com seu próprio corpo. Portanto, a mulher, além de ser um corpo aberto e perfurado, é também um corpo distribuído e dado em alimento. Assim como a mãe terra alimenta seus filhos com os frutos de seu ventre fecundo, assim a mulher alimenta os seres vivos que gera e dá à luz em seu corpo com o próprio corpo.

\section{Corporeidade repartida e distribuída para que todos tenham vida}

A corporeidade feminina traz em si uma outra forte carga simbólica além das já mencionadas e que pode iluminar a questão da conversão ecológica hoje. Trata-se de sua possível identificação com o sacramento da Eucaristia. O corpo repartido é dado em alimento a outros, a todos os que têm fome e necessitam comer para viver.

Parece-nos que a teologia do sacramento da Eucaristia pode ser interpretada em fecunda identificação da corporeidade feminina com a dinâmica do sacramento (BINGEMER, 2013, p. 399). Em primeiro lugar estão os textos do Novo Testamento, com as palavras da instituição: “Tomai... isto é o meu corpo... dado por vós. Tomai e bebei este é o meu sangue, derramado por vós e por muitos..." (1 Cor 11,23-26). Em seguida, estão as mesmas expressões utilizadas na liturgia e na prática sacramental, tais como "transubstanciação "," presença real "," comunhão", significando que o corpo e sangue do Senhor, sob as espécies de pão e vinho, são dados ao povo como comida e bebida (CATÓLICO ORANTE, 2021n; GRILLO, 2021j) ${ }^{10}$. Na liturgia pós Vaticano II, nos ritos católicos da consagração, recorda-se que essas espécies encontram sua raiz na terra e no trabalho humano:

${ }^{10}$ Note-se que após o Concilio a doutrina da transubstanciação tem conhecido discussões e debates que refletem o movimento da fé cristã e entendem o dogma como algo dinâmico e compatível com o diálogo ecumênico e intercultural. 
"...fruto da terra e do trabalho humano..."11, Os dons da mãe terra são a matéria que, em união com o trabalho humano, são transubstanciados em corpo e sangue de Cristo e alimentarão os fiéis para a vida em plenitude.

Alimentar os outros com seu próprio corpo é o caminho maior que o próprio Deus escolheu para estar-realmente-presente no meio de seu povo, unindo sua vida à vida de toda a criação, da terra inteira, fazendo-a uma só vida com a sua, um só corpo com Seu corpo.

Para a comunidade cristã reunida, o pão partido e partilhado, que se confessa corpo de Cristo, remete ao grande mistério da sua Encarnação, Vida, Morte e Ressurreição. Recapitula o itinerário da vinda da divindade à criação assumindo-a inteiramente desde dentro e reconduzindo tudo que é criado ao seu seio amoroso, materno e paterno. O sacramento sinaliza sua pessoa e seu corpo dados em e como alimento. E assim, toda a sua vida, seu corpo e seu sangue, toda a sua pessoa, se torna fonte de vida para aqueles e aquelas que dele comem e bebem.

Os ritos eucarísticos são realizados na missa católica pelos presbíteros devidamente ordenados para tal. Porém, antropologicamente, são as mulheres, aquelas que carregam em sua corporeidade a inscrição e a possibilidade real de tornar visível a ação divina eucarística no meio do mundo e na comunidade.

Durante todo o processo de gestação, parto, proteção, cuidado e alimento da nova vida, pode-se contemplar o sacramento da Eucaristia, ato divino por excelência. O corpo feminino foi penetrado por outro e recebeu de outro suas sementes. A geração da vida em seu interior o fez habitado de forma que não é mais um, mas múltiplo. A alteridade está para sempre hospedada e viva nesta corporeidade que se abriu para recebê-la. No parto o corpo se parte e se divide, entregando seu fruto ao mundo. Porém essa alteridade, essa nova vida que saiu do corpo da mãe seguirá sendo seu corpo caminhando e vivendo nas trilhas de terra, devendo ser alimentado com o corpo da mãe que o amamenta em seu seio, dando-lhe a comer e beber seu corpo e seu sangue no leite que sai de seus peitos túrgidos e bem-aventurados (Lc 11, 27). O corpo feminino é múltiplo e extensivo, é vida gerando novas vidas. É corpo partido, dividido, comido e bebido, fazendo acontecer vida plena para as pessoas que por sua vez vivem e fazem viver o corpo da terra. A força simbólica deste sacramento central na fé cristã é constitutiva da corporeidade feminina e tem sido o centro de experiências místicas por parte de muitas mulheres.

Poderíamos exemplificar o que aqui dizemos em vários relatos de mulheres místicas que fizeram a experiência de desejos e entregas vitais de

\footnotetext{
${ }^{11}$ Cf. as palavras do ofertório, quando são oferecidos o pão e o vinho, "fruto da terra e do trabalho humano..."
} 
configuração eucarística. Muitas delas jamais foram mães biológicas, como a carmelita Terezinha de Jesus ou a judia Etty Hillesum (TEREZINHA DO MENINO JESUS, 2002; HILLESUM, 2020). Relatamos, no entanto, aqui, a experiência de outra mística, filósofa e intelectual do século XX. De origem judia, foi agnóstica até a idade adulta, fazendo a experiência de ser tomada por Cristo já perto de seus 30 anos. Apesar disso, não foi batizada até o momento de sua morte (LUSSY; CANCIANI, 1999; WEIL, 2019; BINGEMER, 2014). Trata-se da francesa Simone Weil.

Durante sua vida, SW viveu a experiência do trabalho moderno e também do trabalho manual, esse último em contato com a terra. A filósofa valoriza muito em seu pensar o trabalho manual juntamente com o corpo daqueles e daquelas que o realizam e que nesse trabalho entram em comunhão com a terra, integrando corpo e espírito ao tocar a concretude e a beleza do mundo. SW foi uma contemplativa que sempre se sentiu atraída e maravilhada pela beleza do mundo. Mas isto não lhe bastou. Experimentou igualmente em seu corpo o contato direto com a terra através do trabalho agrícola.

Nesse contato, aparecem o gozo e a dor, pois há uma negociação permanente com a ordem da necessidade natural. Nesta relação e nesse confronto, a filósofa faz a experiência de sua finitude e dos limites que a natureza lhe impõe e que a ajudam a apalpar sua condição humana (WEIL, 1957, p. 110-112). No verão de 1929, antes de sua experiência na fábrica, desejava trabalhar com os camponeses. Foi para a casa de uma de suas tias, no Jura francês. Extraía batatas da terra dez horas por dia. Conversava com a população e se tornou amiga das famílias locais (PÉTREMENT, 1973, p. 148).

O contato com a terra no trabalho agrícola exige movimentos do corpo e, por isso, segundo SW, é fonte de conhecimento, já que tais movimentos devem ser desejados e pensados antes de atingir seu objetivo, prolongando, de certa maneira, o corpo humano. Assim, segundo ela, "o homem sairia do imaginário e se conformaria à verdadeira relação entre as coisas" (WEIL, 1951, p. 216-223). E o trabalho poderia se tornar transfiguração e até mesmo uma "forma de santidade" (WEIL, 1951, p. 157-158).

Em Marseille, durante a guerra, seu amigo e confidente, o Pe. Perrin, a apresentará a Gustave Thibon que lhe permitirá trabalhar em sua propriedade rural. Este testemunhará que o desejo de SW era experimentar em seu corpo o despojamento e as fadigas que são parte do trabalho agrícola. Por outro lado, percebeu igualmente nela um profundo amor pela terra, por sua beleza, fertilidade, o que a enchia de um profundo gozo mesmo em meio a fadigas extremas assumidas por vontade própria. É o próprio Thibon que fala: "eu a encontrei diante de casa, sentada sobre um tronco e mergulhada na contemplação do vale do Rhône. Vi então seu olhar emergir pouco a pouco da visão para voltar à vista: a intensidade, a pureza desse olhar eram tais que se sentia que ela contemplava abismos interiores 
ao mesmo tempo que o esplêndido horizonte que se abria a seus pés e que a beleza de sua alma correspondia à terna majestade da paisagem". (THIBON, 1952, p. 129).

Mais tarde, quando começou a colheita da uva, Thibon testemunhou que ela trabalhava a terra com uma energia inflexível» (PÉTREMENT, 1973, p. 351). À noite, sentava-se com ele e liam juntos páginas de Platão em grego. E ele por sua vez lhe emprestava as obras de São João da Cruz (PÉTREMENT, 1973, p. 353).

À sua amiga e biógrafa Simone Petrement, SW explicava seu aprendizado trabalhando a terra. Apesar de todo o cansaço e dificuldade que nesse trabalho encontrava, - juntamente com os sofrimentos que eram os seus e de sua família enquanto judeus exilados, deixando para trás a França e esperando o transporte para o exílio em Nova York - experimentava igualmente uma imensa alegria.

As fadigas de meu corpo e de minha alma se transformarão em alimento em meio a um povo que tem fome." (PÉTREMENT, 1973, p. 361). [...] Devo dizer que para mim o pensamento de transformar as fadigas de meu corpo e minha alma em batatas e coisas desse gênero em meio a um povo que terá fome é a única coisa que pode me excitar neste momento. (1973, p. 364)

A terra, portanto, na mística de SW, é fonte de uma experiência que combina fadiga e alegria. Como escreve ao refugiado espanhol e amigo Antonio Atarez: “...a fadiga é uma fadiga sadia para a alma, porque põe em contato mais completo com a natureza, ao fundo da qual se encontram alegrias profundas..." (PÉTREMENT, 1973, p. 373). A alegria experimentada aparece em seu relato ao amigo Pierre Honorat:

Eis-me transformada em vindimadora, trabalho duro, mas que eu amo... Sinto cada vez mais que é bem isto que devo fazer. Por que, seria para mim impossível de explicar: e por que procurar explicar? O que se sente dever fazer, poema ou colheita de uva, é preciso fazê-lo, eis tudo... (PÉTREMENT, 1973, p. 373).

A terra desvendou seus segredos à mulher intelectual e mística que foi SW e lhe revelou ser sua corporeidade aberta, perfurada e fecunda para repartir-se e dar vida, assim como terra que trabalhava. Ao mesmo tempo, é nesse período que se encontra sua maior fecundidade em termos de produção intelectual. Por isso mesmo escreve a seu amigo e interlocutor espiritual, o Pe. Perrin, agradecendo ter-lhe "aberto a terra" (PÉTREMENT, 1973, p. 377). Ela utiliza expressão parecida em carta irônica a Xavier Vallat, comissário francês para as questões judaicas. Após dizer-lhe que o governo de Vichy jamais formalizou sua saída do ensino público - ocorrida devido a sua origem judia - ela lhe agradece por isso.

Faço questão de exprimir-lhe meu reconhecimento sincero pelo fato do governo me haver retirado da categoria social dos intelectuais e me haver dado a terra e com ela toda a natureza. Pois só possuem a natureza e a terra aqueles em 
cujos corpos elas entraram pelo sofrimento cotidiano dos membros rotos de fadiga. Os dias, os meses, as estações, a abóbada celeste... pertencem àqueles que devem ultrapassar o espaço de tempo que separa cada dia da aurora e do pôr do sol, indo penosamente de fadiga em fadiga. Estes... vivem cada dia e não o sonham (PÉTREMENT, 1973, p. 378).

Examinando teologicamente a experiência mística de SW com a terra, vemos que se trata de uma experiência profunda de comunhão. Comunhão com os trabalhadores agrícolas em suas fadigas no seio de seu trabalho na terra. Comunhão com a própria terra, mãe de dons múltiplos, seio fecundo do qual se extrai o alimento e o líquido que desaltera, com a condição de consentir em entregar seu corpo em recíproca interatividade com ela.

O desejo de SW com sua experiência com a terra não é a dor ou a fadiga em si mesmas. Mas são os outros, os pobres, o povo que tem fome. Por eles esse mergulho no trabalho manual do campo, onde procura avidamente a relação íntima com a vida dos camponeses. Estar no mundo para SW significa integrar tudo que vive, começando inevitavelmente por tudo que está à margem e é mais vulnerável. A esses, à sua vulnerabilidade é preciso entregar o corpo, distribuído para saciar a fome e a sede dos que perecem na carência e na necessidade. Essa mulher que não viveu a maternidade biológica experimenta uma maternidade maior e universal ao viver um contato corpóreo e íntimo com a maternidade da terra.

\section{Conclusão}

O percurso que procuramos fazer pela corporeidade feminina - das mulheres e da terra -, parece-nos poder ajudar a repensar o lugar do feminino no contexto em que hoje vivemos. Fonte de tanta suspeita e preconceito ao longo da história, o corpo feminino é um caminho poderosamente iluminador e inspirador para a teologia cristã hoje. Com mais razão reiteramos essa afirmação em meio à emergência da crise ecológica na qual vivemos. A teologia ecofeminista apresenta novos paradigmas além das sempre presentes questões de gênero. Recorda interpretações presentes na tradição espiritual e mística da Igreja, que celebra a imagem de Deus como Abba pai amoroso, mas igualmente como mãe que alimenta e nutre os filhos com o leite do peito (BINGEMER, 2013).

Tal configuração simbólica e teológica do corpo da mulher não tem impacto apenas em um nível pessoal, mas carrega implicações comunitárias e políticas. Ser um corpo aberto, receptivo e fecundo, capaz de dar vida e cuidar da vida, até alimentá-la eucaristicamente, tem impacto em todos os atos e movimentos que as mulheres realizam e, muitas vezes, em sua influência pública efetiva. Mesmo expondo no espaço público sua característica mais privada, como a abertura de seu "bios", seguida da capacidade de dar 
vida e todos os aspectos da maternidade, o corpo feminino pode causar um impacto de grande importância ética e política. Pode revelar o passo necessário do privado ao público, da câmara nupcial do amor vivido na intimidade à presença pública solidária e comprometida (WEIL, 1966, p. 45-46). Corpo dado por muitos para a libertação de todos.

Essa configuração corpórea é igualmente a da Mãe Terra, criação de Deus: corpo fértil e fecundo, mas sugado em sua força e recursos, atacado em suas potencialidades, diminuído em suas possibilidades, esmagado em sua força vital. Seus ciclos, sua gravidez lenta e progressiva, seu útero fértil não são respeitados. Seu corpo não é acariciado nem seus desejos satisfeitos, a fim de que as sementes se abram em flores exuberantes e frutos maduros e sumarentos. Em vez disso, muitas vezes encontra-se seco como a ossatura da pelve ressecada que parece não produzir mais vida no estado em que se encontra. Mesmo assim, a terra mãe continua alimentando seus filhos com o que lhe resta de forças vitais e potencial fertilidade. Foi criada por Deus que é Vida em Si mesmo e, portanto, só cria aquilo que multiplica a vida. No entanto, o corpo da terra - assim como o da mulher - não é inexaurível e eterno como Seu criador. Cabe a nós cuidar que seus recursos não se esgotem e que ela continue a ser a mãe de seio túrgido que a todos satisfaz com seus frutos.

Tal como a terra, também muitas mulheres experimentam o desrespeito e a agressão a seus corpos: grávidas sob violência, gerando filhos em decorrência de estupros que às vezes ocorrem dentro da própria casa; dando à luz nas condições mais adversas, mas ainda assim fazendo a vida triunfar sobre a morte ao ouvir o choro do recém-nascido; vivendo uma corporeidade extensiva, que se multiplica em muitos filhos, no ventre, ao seio, nos braços etc.; dando a última gota que lhes resta no corpo para alimentar a cria que grita de fome, terminando por alimentá-la com leite e sangue; esterilizadas pela contínua humilhação e violência a que são submetidas. Este é o mistério do feminino que ao longo dos tempos permite que a espécie humana continue viva.

O ser humano é convocado hoje a refazer a experiência espiritual de união afetiva e real com a Terra, a fim de resgatar suas raízes e vivenciar sua própria identidade radical. Também deve reavivar a memória espiritual e política do feminino para que esta dimensão e identidade fecundas e maternas entrem na elaboração de políticas públicas resultando em mais equidade entre os sexos e maior capacidade de integração. A experiência de Deus como Mãe infinita e misericordiosa emergirá desse processo.

Emergirá igualmente uma outra ética, concentrada em cuidar de tudo que vive. No novo paradigma emergente, a Terra e os filhos e filhas da Terra serão de grande centralidade, realizando talvez o sonho do século XXI: a justiça e a paz pela qual todos anseiam, fruto da reconciliação do ser humano com todos os seres e com suas raízes telúricas, com a Fonte 
Geradora de todo o ser - a Mãe Terra - coexistindo na Casa Comum. A divisão entre o espiritual e o corporal, entre a razão e a matéria, entre o que está acima e o que está abaixo nos tornou seres divididos. Urge reintegrar-nos para reencontrar nossa identidade.

Essa mística e essa ética iluminarão o caminho de volta à Casa da Mãe, do qual já se veem sinais importantes, sendo um deles o pensamento ecofeminista. Sua tarefa é reconstruir o corpo da terra, o corpo humano e a humana relação com todos os corpos viventes. E seu sonho é fazer avançar o reconhecimento fundamental de que "somos um só Corpo Sagrado com todos os seus matizes e diversidade" (RESS, 2010).

\section{Referências}

ADINOLFI, M. Il Femminismo della Bibbia. Roma: Tip. R. Ambrosini, 1981.

ALLMEN, J.-J. Vocabulário bíblico. São Paulo: ASTE, 2001.

ARMSTRONG, K. Uma história de Deus. São Paulo: Companhia das Letras, 1994.

AUR, D. Religiões representadas por divindades femininas e o culto às deusas. Disponível em: https://www.greenme.com.br/viver/arte-e-cultura/80525-religioes-representadas-divindades-femininas-culto-deusas/. Acesso em: 27 de jul. 2021.

BEZERRA, K. História geral das religiões. Disponível em: https://webcache.googleusercontent.com/search?q=cache:Qq_I8yd_n2cj:https://www1.unicap.br/observatorio2/ wp-content/uploads/2011/10/HISTORIA-GERAL-DAS-RELIGIOES-karina-Bezerra. pdf. Acesso em: 27 jul. 2021.

BINGEMER, M. C. A Trindade a partir da perspectiva da mulher (algumas pistas de reflexão). Revista Eclesiástica Brasileira, Petrópolis, v. 46, n. 181, p. 73-99, março de 1986.

BINGEMER, M. C. Ecologia e salvação. In: VV.AA. Reflexão cristã sobre o meio ambiente. São Paulo: Loyola, 1992, p. 77-87.

BINGEMER, M. C. Masculinidade e feminilidade: duas faces do mistério de Jesus Cristo. Concilium, Petrópolis, n. 326, v. 3, p. 45-56, 2008.

BINGEMER, M. C. A Eucaristia e o corpo feminino: (Presença real Transubstanciação, Comunhão). Perspectiva Teológica, Belo Horizonte, v. 127, n. 45, p. 399-418, set/dez. 2013.

BINGEMER, M. C. Simone Weil: mística da paixão e da compaixão. São Paulo: EDUSC, 2014.

BOFF, L. O rosto materno de Deus. Petrópolis: Vozes, 1987.

BOFF, L. Saber cuidar: ética do humano - compaixão pela terra. Petrópolis: Vozes, 1999.

BOFF, L. Qué significa ser y sentirse tierra. Exodo, Madrid, n. 53, p. 30-32, abr. 2000. 
BOFF, L.; MURARO, R. M. Feminino e Masculino. São Paulo: Sextante, 2002.

BOFF, L. Covid 19: a Mãe Terra contra ataca a humanidade. Petrópolis: Vozes, 2021.

BOFF, L. Eco-espiritualidade: que significa ser e sentir-se Terra?. Disponível em: www.leonardoboff.com. Acesso em: 28 jul. 2021.

BOFF, L. Identidade e complexidade. Disponível em: http://www.dhnet.org.br/desejos/ textos/galaxy.html. Acesso em: 26 jul. 2021.

BORRESEN, K. E. Fundamentos Antropológicos da Relação entre o Homem e a Mulher na Teologia Clássica. Concilium, Petrópolis, n. 111, v. 1, p. 18-29, 1976.

BORRESEN, K. E. “God's Image, Man's Image?: Female Metaphors Describing God in the Christian Tradition". Helsinki: EIGE, 1983.

BRANDÃO, J. S. Mitologia Grega. Petrópolis: Vozes, 2015. 3 v.

BROWN, P. Corpo e sociedade. São Paulo: Zahar, 1990.

CANDIOTTO, J. S. A teologia ecofeminista e sua perspectiva simbólico/cultural. Horizonte, Belo Horizonte, v. 10, n. 28, p. 1395-1413, out/dez. 2012.

CANDIOTTO, J. S. A experiência de mulheres na hermenêutica bíblica. Interações Cultura e Comunidade, Belo Horizonte, v. 10, n. 17, p. 200-215, jan./jun.2015.

CATÓLICO ORANTE. Liturgia Eucarística. Disponível em : https://www.catolicoorante.com.br/leucaristica.html. Acesso em: 2 ago. 2021n.

COSTA, M. R. N. A relação corpo-alma no homem, segundo Santo Agostinho: dualismo ou unidade substancial?, Enrahonar: Suplement Issue, 2018.

DELLAZARI, R. Theologisches Wörterbuch zum Alten Testament. Façamos o adam. O ser humano como outro e outra. Teocomunicação, Porto Alegre, v. 36, n. 154, dez. 2006.

EVA. In: Dicionário de nomes próprios. Disponível em: https://www.dicionariodenomesproprios.com.br/eva/. Acesso em: 26 jul. 2021g.

FLICKR. Photos. Disponível em: https://www.flickr.com/photos/amyallcock/3719181290/ Acesso em: 28 jul. 2021i.

GEBARA, I. Teologia ecofeminista: ensaio para repensar o conhecimento e a religião. São Paulo: Olho d'Água, 1997.

GRILLO, A. Presença real e transubstanciação: conjecturas e esclarecimentos. Disponível em: http://www.ihu.unisinos.br/78-noticias/574938-presenca-real-e-transubstanciacao-conjecturas-e-esclarecimentos-artigo-de-andrea-grillo. Acesso em: 02 ago. 2021j.

HILLESUM, E. Diário 1941-1943. Lisboa: Assírio Alvim 2020.

KRISTEVA, J. La haine et le pardon. Paris: Fayard, 2005.

KRISTEVA, J. Seule une Femme. Paris: L'Aube, 2007.

KRISTEVA, J. Pulsions du temps. Paris, Fayard, 2013.

KRISTEVA, J.; CLEMENT, C. Le féminin et le sacré. Paris: Albin Michel, 2015.

LUSSY, F.; CANCIANI, D. Oeuvres. Paris : Quarto Gallimard, 1999. v. 1. 
MASDEARTE.COM. Lo que significa la flor para Georgia O'Keeffe. Disponível em: https://masdearte.com/especiales/lo-que-significa-la-flor-para-georgia-okeeffe/. Acesso em: 28 jul. 2021k.

MIGNOLO, W. Colonialidade: o lado mais escuro da modernidade. Revista Brasileira de Ciências Sociais, São Paulo, v. 32, n. 94, jun. 2017.

MOLTMANN, J. Dieu homme et femme. Paris : Cerf, 1984.

MORAES, D. B. P. M., Yiabás em cena: o trânsito e as representações das divindades femininas no Candomblé. Revista Arte da Cena, Goiânia, v. 3, n. 1, p. 128-142, Jan./jun. 2017.

OKA, M. Entre sexo e gênero: um estudo exploratório-bibliográfico das ciências da saúde. Disponível em: https://www.scielo.br/j/sausoc/a/6DbV8gjdvXspry5QQ7KH KRB/?lang=pt. Acesso em: 27 jul. 20211.

PETREMENT, S. La vie de Simone Weil. Paris: Fayard, 1973. v. 1.

PRADO, A. Poesia Reunida. São Paulo: Siciliano, 1999.

RESS, M. J. Espiritualidad ecofeminista en América Latina. Investigaciones Feministas, Madrid, v. 1, p. 111 - 124, 2010. Disponível em: https://revistas.ucm.es/index.php/ INFE/article/view/INFE1010110111A/7690. Acesso em: 27 jul. 2021m.

ROCHA, N. C. M. Dimensões teológicas da Criação e Salvação na teologia de Pierre Gisel. Atualidade Teológica, Rio de Janeiro, Ano XIV, n. 34, jan./ abr. 2010.

SANTOS, B. S.; MENEZES, M. P. Epistemologias do sul. São Paulo: Cortez, 2010.

SHIVA, V. Abrazar la vida: mujer, ecología y supervivência. Madrid: Horas y horas, 2004.

SOUZA, S. D. Teoria, teo(a)logia e espiritualidade ecofeminista: uma análise do discurso. Mandrágora, São Bernardo do Campo, n. 6, p. 57-64, dez. 2000.

STEINER, J. E. Origem do universo e do homem. Estudos Avançados, São Paulo, v. 20, n. 58, p. 231-248, 2006.

THIBON, G.; PERRIN, J. M.. Simone Weil telle que nous l'avons connue. Paris : La Colombe, 1952.

TERESINHA do Menino Jesus, Santa. História de uma alma. São Paulo: Paulus, 2002.

TORRÃO, A. F. Uma questão de gênero: onde masculino e feminino se cruzam. Disponível em: https://www.scielo.br/j/cpa/a/9qWCTLfW8Qvr9bTspS9dSsd/?lang =pt. Acesso em: 27 jul. 2021n.

WEIL, S. La personne et le sacré. Ecrits de Londres et dernières lettres. Paris: Gallimard, 1957. (Collection Espoir).

WEIL, S. Espera de Deus. Petrópolis: Vozes, 2019.

WEIL, S. Condition première d'un travail non servile. La condition ouvrière. Paris: Gallimard, 1951.

WEIL, S. Attente de Dieu, version numérique, 1966. O’KEEFFE, G. In: WIKIPÉDIA, a enciclopédia livre. Flórida: Wikimedia Foundation, 2020. Disponível em: $<$ https:// pt.wikipedia.org/w/index.php?title=Georgia_O\%27Keeffe\&oldid=58183609>. Acesso em: 28 jul. 2021o. 
ZOLLI, E. Israele. Studi storico-religiosi. Udine, [S.n.] 1935.

YOUTUBE. Cio da Terra. Disponível em: https://www.youtube.com/ watch?v=sB2uIJBzzsU Acesso em: 25 jul 2021h.

WIKIPÉDIA. Deusa-mãe. Disponível em: <https://pt.wikipedia.org/w/index. php?title=Deusa-m\%C3\%A3e\&oldid=61071486>. Acesso em: 27 jul. 2021a.

WIKIPÉDIA. Religião no antigo Egito. Disponível em: <https://pt.wikipedia.org/w/ index.php?title=Religi\%C3\%A3o_no_Antigo_Egito\&oldid=60291865>. Acesso em: 27 jul. $2021 b$.

WIKIPÉDIA. Lista de figuras da mitologia grega. Disponível em: $<$ https://pt.wikipedia. org/w/index.php?title=Lista_de_figuras_da_mitologia_grega\&oldid=61449905>. Acesso em: 23 jul. 2021c.

WIKIPÉDIA. Hércules. Disponível em: <https://pt.wikipedia.org/w/index.php?title $=\mathrm{H} \% \mathrm{C} 3 \%$ A9rcules\&oldid=61717969>. Acesso em: 27 jul. 2021d.

WIKIPÉDIA. Feminicídio. Disponível em: <https://pt.wikipedia.org/w/index.php?tit le=Feminic\%C3\%ADdio\&oldid=61559768>. Acesso em: 29 jul. 2021e.

WIKIPÉDIA. Georgia O’keeffe. Disponível em: https://pt.wikipedia.org/wiki/ Georgia_O\%27Keeffe. Acesso em: 27 jul. $2021 \mathrm{f}$.

Artigo submetido em 13.08.2021 e aprovado em 16.11.2001.

Maria Clara Lucchetti Bingemer é doutora em Teologia Sistemática pela Pontifícia Universidade Gregoriana. Atualmente é professora titular no Departamento de Teologia da PUC-Rio e coordenadora da Cátedra Carlo Maria Martini CTCH/PUC-Rio. Orcid.org/0000-0003-34438214. E-mail: agape@puc-rio.br

Endereço: Rua Almirante Salgado, 51 Laranjeiras 22240-170 Rio de Janeiro - RJ 